\title{
СИСТЕМА АДМИНИСТРАТИВНО-ПРАВОВЫХ СРЕДСТВ ПРОТИВОДЕЙСТВИЯ КОРРУПЦИИ В ТАМОЖЕННЫХ ОРГАНАХ РОССИЙСКОЙ ФЕДЕРАЦИИ
}

A ктуальность проблемы противодействия коррупции в современной России чрезвычайно высока, т.к. коррупция в органах государственной власти приобрела в настоящее время глобальный и системный характер. Коррупция относится к числу наиболее опасных негативных социальных явлений, приводящих к разрушению основ правопорядка и резко ослабляющих все государственные институты ${ }^{1}$. Она обладает рядом негативных свойств, которые ставят её в ряд опаснейших социальных проблем: представляет собой непосредственную угрозу национальной безопасности, препятствует развитию в нашей стране институтов демократии и гражданского общества, реализации гражданами своих прав. Главным и очевидным последствием распространения коррупции является снижение эффективности деятельности субъекта власти, в крайней своей форме выливающееся в паралич. Социальная же сущность коррупции - в деградации аппарата публичной власти: коррумпированный аппарат уже не пригоден для отправления свойственных ему функций, бесполезен для общества.

Таможенные органы, обладающие распорядительными и контрольными функциями, способные повлиять на движение значительных денежных потоков, естественным образом подвергаются действию коррупциогенных факторов, коррупционных тенденций, что определяет специфику противодействия корруп-

1 Астанин В.В. Научно-практический комментарий к Федеральному закону от 25 декабря 2008 г. № 273-Ф3 “О противодействии коррупции”. - СПб.: “Юридический центр Пресс”, 2009. ции среди их должностных лиц. Таможенные органы, являясь частью системы исполнительных органов государственной власти РФ, также частично подвержены коррупционным проявлениям. Между тем, высокая эффективность функционирования таможенных органов особенно важна в современной России, т.к. из-за особенностей экономики именно таможенная службы на сегодняшний день обеспечивают больше половины поступлений в федеральный бюджет. Так, за 2012 г. сумма доходов федерального бюджета, администрируемых таможенными органами, составила более 6 трлн. рублей, а за шесть месяцев 2013 г. - 3036,78 млрд руб. ${ }^{2}$

В настоящее время правовую основу антикоррупционной политики РФ составляет Федеральный закон от 25 декабря 2008 г. № 273-Ф3 «О противодействии коррупции» (далее - Федеральный закон о противодействии коррупции).

Согласно указанному закону коррупция - это злоупотребление служебным положением, дача взятки, получение взятки, злоупотребление полномочиями, коммерческий подкуп либо иное незаконное использование физическим лицом своего должностного положения вопреки законным интересам общества и государства в целях получения выгоды в виде денег, ценностей, иного имущества или услуг имущественного характера, иных имущественных прав для себя

Справочные материалы к заседанию Коллегии ФТС России «Таможенная служба Российской Федерации в 2012 г.».M., 2013. 
или для третьих лиц либо незаконное предоставление такой выгоды указанному лицу другими физическими лицами, а также совершение вышеуказанных деяний от имени или в интересах юридического лица.

Структура Федерального закона о противодействии коррупции отражает замысел законодателя, стремившегося, используя комплексный подход, задействовать максимально возможное количество рычагов, имеющихся в руках органов государственной власти. Вывод о том, что коррупция является социальным явлением, корни которого исходят из недостатков организации государственной службы и из-за особенностей психологии её персонала, диктует необходимость принятия широкого спектра средств антикоррупционного характера, и, прежде всего - административно-правовых и организационно-управленческих ${ }^{3}$.

Административное право представляет собой отрасль правовой системы РФ, которая призвана регулировать особую группу общественных отношений. Главная их особенность состоит в том, что они возникают, развиваются и прекращаются в сфере государственного управления, т.е. в связи с организацией и функционированием системы исполнительной власти на всех национально-государственных и территориальных уровнях страны. Главное, что характерно для регулятивной роли административного права и в чем в наибольшей степени проявляются его особенности - это функционирование системы исполнительной власти. Соответственно административное право фактически выступает в качестве юридической формы реализации задач, функций, методов и полномочий, возлагаемых Конституцией и законодательством РФ на субъектов исполнительной власти, действующих в рамках разделения властей ${ }^{4}$.

Учитывая изложенное, представляется верной точка зрения, что коррупция, как явление, представляющее собой прежде всего дефект государственного управления, находится в сфере действия административного права.

Анализ нормативной базы показывает, что борьба с коррупционными правонарушениями на сегодняшний день является одним из приоритетных направлений деятельности государства. Несмотря на тенденцию к смягчению уголовного законодательства, замену сроков заключения на наказания экономического

\footnotetext{
Куракин А.В. Административно-правовые средства предупреждения и пресечения коррупции в системе государственной службы Российской Федерации: дис. ... д-ра юрид. наук. - Люберцы, 2008.

4 Козлов Ю.М., Овсянко Д.М., Попов Л.Л. Административное право: учебник. «Юристъ». - М., 2000.
}

характера и декриминализацию некоторых составов преступлений, ответственность за правонарушения коррупционного характера становится строже. Так, ответственность за отдельные составы преступлений в соответствии с Федеральным законом от 4 мая 2011 г. № 97-Ф3 «О внесении изменений в Уголовный кодекс Российской Федерации и Кодекс Российской Федерации об административных правонарушениях в связи с совершенствованием государственного управления в области противодействия коррупции» (далее - Федеральный закон № 97-Ф3) была изменена в сторону увеличения строгости: установлены кратные, зависящие от фигурирующей в деле суммы, штрафы за коммерческий подкуп, получение и дачу взятки, посредничество во взяточничестве.

Вместе с тем одних лишь уголовных методов для полноценного противодействия коррупции явно недостаточно. Так, по словам Н.М. Коркунова «уголовная репрессия слишком дорого обходится обществу и материально, и нравственно, вместе с тем, сама уголовная кара не уничтожает совершившегося правонарушения, сама по себе не восстанавливает попранного права, не возмещает причинённого преступником вреда. К карательным мерам приходится прибегать, когда нет других способов противодействия правонарушению, или способы эти недостаточны, не соответствуют тяжести противозаконного посягательства. В связи с чем, недаром законы с карательной санкцией называются менее совершенными законами ${ }^{5}$.

Анализ антикоррупционного законодательства РФ позволяет сделать вывод о том, что административно-правовые методы противодействия коррупции получают всё большее распространение. Федеральным законом № 97-Ф3 значительно увеличен срок давности привлечения к административной ответственности за нарушение законодательства РФ о противодействии коррупции - с одного года до шести лет. Кроме того, законом внесены значительные изменения в ст. 19.28 Кодекса об административных правонарушениях Российской Федерации (далее КоАП РФ) «Незаконное вознаграждение от имени юридического лица» в части расширения объективной стороны состава правонарушения, а также в части установления более строгого наказания. Статьёй 19.29 КоАП РФ установлена административная ответственность за привлечение к трудовой деятельности либо к выполнению работ или оказанию услуг государственного или муниципального служащего либо бывшего государственного или муниципального слу-

\footnotetext{
Коркунов Н.М. Русское государственное право. - Т. 2. Часть особенная. - СПб., 1909. - с. 694.
} 
жащего с нарушением требований Федерального закона о противодействии коррупции.

Система административно-правовых мер противодействия коррупции в сформирована в Федеральном законе о противодействии коррупции и Указах Президента РФ, изданных в развитие его положений:

1. Обязанность предоставлять сведения о доходах, обязательствах имущественного характера, а также о доходах, об имуществе и обязательствах имущественного характера своих супруги или супруга и несовершеннолетних детей гражданами, претендующими на замещение должностей федеральной государственной службы, и государственными служащими является важной частью системы антикоррупционных мер. Положение о представлении гражданами, претендующими на замещение должностей федеральной государственной службы, и государственными служащими сведений о доходах, об имуществе и обязательствах имущественного характера, а также формы справок, в которых данные сведения указываются, утверждены Указом Президента РФ от 18 мая 2009 г. № 559.

Единый порядок и единые формы справочных документов позволяют говорить о создании в перспективе единой государственной электронной базы данных.

Перечень должностей федеральной государственной службы, при назначении на которые граждане и при замещении которых федеральные государственные служащие (далее - государственные служащие) обязаны представлять сведения о своих доходах, об имуществе и обязательствах имущественного характера, а также сведения о доходах, об имуществе и обязательствах имущественного характера своих супруги (супруга) и несовершеннолетних детей утвержден Указом Президента РФ от 18 мая 2009 г. № 557. Отдельно необходимо отметить, что пункт 2 названного указа содержит предписание руководителям федеральных государственных органов утвердить в соответствующих федеральных государственных органах перечни конкретных должностей федеральной государственной службы, подпадающих под требования раздела III указа. Таким образом, исключается возможность возникновения правового вакуума в части определения круга лиц, на которых распространяется обязанность предоставлять вышеназванные сведения.

2. Порядок и процедура проверки достоверности и полноты сведений о доходах, об имуществе и обязательствах имущественного характера, о доходах, об имуществе и обязательствах имущественного характера супруги (супруга) и несовершенно- летних детей, представленных лицами замещающими или претендующими на замещение как государственных должностей, так и должностей федеральной государственной службы детально регламентированы Указами Президента РФ № 1065, 1066 и 309.

3. Указом Президента РФ от 21 июля 2010 г. № 925 установлена обязанность граждан, замещавших должности федеральной государственной службы, включенную в раздел I или раздел II перечня должностей федеральной государственной службы, при назначении на которые граждане и при замещении которых государственные служащие обязаны представлять сведения о своих доходах, об имуществе и обязательствах имущественного характера, а также сведения о доходах, об имуществе и обязательствах имущественного характера своих супруги (супруга) и несовершеннолетних детей, утвержденного Указом Президента РФ от 18 мая 2009 г. № 557, или должность федеральной государственной службы, включенную в перечень должностей федеральной государственной службы в федеральном государственном органе, при назначении на которые граждане и при замещении которых государственные служащие обязаны представлять сведения о своих доходах, об имуществе и обязательствах имущественного характера, а также сведения о доходах, об имуществе и обязательствах имущественного характера своих супруги (супруга) и несовершеннолетних детей, утвержденный руководителем федерального государственного органа в соответствии с разделом III перечня, утвержденного Указом Президента РФ от 18 мая 2009 г. № 557, в течение двух лет со дня увольнения с федеральной государственной службы.

Со вступлением в силу данного указа был ликвидирован пробел в законодательстве, не позволявший привлечь недобросовестного гражданина ни к уголовной (ввиду отсутствия состава преступления), ни к дисциплинарной ответственности (ввиду того, что дисциплинарные правоотношения возможны лишь между работодателем и работником). Таким образом, законодатель использовал в сфере противодействия коррупции административно-правовые средства там, где дисциплинарное производство оказалось бессильно.

4. Федеральным законом от 3 декабря 2012 г. № 230-Ф3 «О контроле за соответствием расходов лиц, замещающих государственные должности, и иных лиц их доходам» и Указом Президента РФ № 310 установлены правовые основы осущест- 
вления контроля за соответствием расходов лиц, замещающих государственную должность либо должность государственной службы, расходов его супруги (супруга) и несовершеннолетних детей общему доходу данного лица и его супруги (супруга) за три последних года, предшествующих совершению сделки, а также определены категории лиц, в отношении которых осуществляется контроль за расходами, порядок осуществления контроля за расходами. Отдельно необходимо подчеркнуть, что вышеназванным федеральным законом регламентирован механизм обращения в доход РФ имущества, в отношении которого не представлено сведений, подтверждающих его приобретение на законные доходы, представленных лицами, замещающими или претендующими на замещение как государственных должностей, так и должностей федеральной государственной службы. Так как коррупция - всегда корыстное правонарушение, то именно лишение субъектов правонарушения материальной выгоды является, на наш взгляд, наиболее эффективной мерой противодействия.

5. Указом Президента РФ от 1 июля 2010 г. № 821 определён порядок формирования и деятельности комиссий по соблюдению требований к служебному поведению федеральных государственных служащих и урегулированию конфликта интересов, образуемых в федеральных органах исполнительной власти. Необходимо подчеркнуть, что комиссии не рассматривают сообщения о совершении преступлений или административных правонарушений, а также не проводит проверки по фактам нарушения служебной дисциплины. Специфическим предметом ведения комиссий являются вопросы, связанные с соблюдением государственными служащими ограничений и запретов, требований о предотвращении или урегулировании конфликта интересов, а также в обеспечении исполнения ими обязанностей, предусмотренных Федеральным законом о противодействии коррупции.

На основании вышеизложенного можно с уверенностью утверждать, что в федеральном законодательстве в настоящее время формируется система административно-правовых средств противодействия коррупции. Ведомственные нормативные правовые акты, приведённые в соответствие с перечисленными федеральными законами и указами, образуют правовую основу противодействия коррупции в таможенных органах РФ.

\section{Библиографический список:}

1. Астанин В.В. Научно-практический комментарий к Федеральному закону от 25 декабря 2008 г. № 273-Ф3 «О противодействии коррупции». - СПб.: «Юридический центр Пресс», 2009.

2. Стрельников К.А. «Вопросы реализации Федерального закона «О противодействии коррупции» // Юридический мир. - 2009. - № 3.

3. Справочные материалы к заседанию Коллегии ФТС России «Таможенная служба Российской Федерации в 2012 году». - М., 2013.

4. Куракин А.В. Административно-правовые средства предупреждения и пресечения коррупции в системе государственной службы Российской Федерации: дис. ... д-ра юрид. наук. - Люберцы, 2008.

5. Козлов Ю.М., Овсянко Д.М., Попов Л.Л. Административное право: учебник. «Юристъ». - М., 2000.

6. Коркунов Н.М. Русское государственное право. - Т. 2. Часть особенная. - СПб., 1909. - С. 694.

\section{References (transliteration):}

1. Astanin V.V. Nauchno-prakticheskii kommentarii k Federal'nomu zakonu ot 25 dekabrya 2008 g. № 273-FZ «O protivodeistvii korrupcii». - SPb.: «Yuridicheskii centr Press», 2009.

2. Strel'nikov K.A. «Voprosy realizacii Federal'nogo zakona «O protivodeistvii korrupcii» // Yuridicheskii mir. — 2009. — № 3.

3. Spravochnye materialy k zasedaniyu Kollegii FTS Rossii «Tamozhennaya sluzhba Rossiiskoi Federacii v 2012 godu». M., 2013.

4. Kurakin A.V. Administrativno-pravovye sredstva preduprezhdeniya i presecheniya korrupcii v sisteme gosudarstvennoi sluzhby Rossiiskoi Federacii: dis. ... d-ra yurid. nauk. - Lyubercy, 2008.

5. Kozlov Yu.M., Ovsyanko D.M., Popov L.L. Administrativnoe pravo: uchebnik. «Yurist'». - M., 2000.

6. Korkunov N.M. Russkoe gosudarstvennoe pravo. - T. 2. Chast' osobennaya. - SPb., 1909. - S. 694. 